\title{
Live in a Nursing Home
}

National Cancer Institute

\section{Source}

National Cancer Institute. Live in a Nursing Home. NCI Thesaurus. Code C113782.

An indication that an individual is living in a nursing home. 